\title{
The effect of ergonomics in dentistry on the occurrence of pain in the cervical neck region of the spine
}

\section{Wpływ ergonomii warunków pracy na występowanie bólów kręgosłupa w odcinku szyjnym u stomatologów}

\author{
Jędrzej Płocki¹, Dominik Pikuła1, Joanna Banaś ${ }^{1}$ Andrzej Kotela²,3 \\ 'Department of Rehabilitation, Holy Family Specialist Hospital, Rudna Mala, Poland \\ Head of the Department: Bożena Sałata MD \\ ${ }^{2}$ Orthopedic and Trauma Clinic, Central Clinical Hospital of the Ministry of Interior, Warsaw, Poland \\ Head of the Department: Prof. Ireneusz Kotela MD, PhD \\ ${ }^{3}$ Department of Rehabilitation in Disease of the Locomotor Institute of Physiotherapy, Faculty of Health Sciences, Jan Kochanowski \\ University (JKU), Kielce, Poland \\ Head of the Department: Prof. JKU Ireneusz Kotela PhD
}

Key words: ergonomics of work, dentistry, back pain, kinesitherapy.

Słowa kluczowe: ergonomia warunków pracy, stomatologia, bóle kręgosłupa, kinezyterapia.

\begin{abstract}
Introduction: The problem of health risks resulting from the performance of the occupation of a dentist concerns, among other things, the cervical region of the spine. Due to the position assumed at work, this part of the spine is overloaded, and the degree of this overload depends, among other things, on the technique used by a dentist, the ergonomic conditions, patient adaptation skills, and cooperation with an assistant or assistants.

Aim of the research: The objective of the study was to obtain an answer to the research questions posed: whether dentists possess knowledge concerning the principles of ergonomics; is there any relationship between the period of employment and cervical spine pain, age, technique of work, duration of performing work during the week, and pain in the neck region; and if dentists attach importance to the prophylaxis of musculoskeletal disorders.

Material and methods: The study covered 52 dentists - 33 females (63.5\%) and 19 males (36.5\%), and was conducted using an anonymous questionnaire designed by the authors, the Visual Analogue Scale (VAS), a modified pain assessment questionnaire according to Laitinen, and methods of descriptive statistics (Pearson's $\chi^{2}$ test for independence).

Results: Physicians possess knowledge concerning the ergonomics of work. In addition, more than $60 \%$ of respondents possess modern, electrically adjustable equipment, and the technique of work depends on the age of the dentist. There is a relationship between cervical spine pain and the duration of performance of the occupation $(p=0.01122)$. According to dentists (48.1\%), pain in the neck region of the spine is caused by long-lasting maintenance of a static position of the body, and kinesitherapeutic exercises alleviate these complaints in $23.1 \%$ of respondents.

Conclusions: Despite the use the principles of ergonomics at work, dentists are exposed to the occurrence of pain in the neck region of the spine.
\end{abstract}

\section{Streszczenie}

Wprowadzenie: Problem zagrożeń zdrowotnych, które wynikają ze sposobu wykonywania zawodu stomatologa, dotyczy m.in. odcinka szyjnego kręgosłupa. Kręgosłup szyjny jest przeciążony ze względu na pozycję przyjmowaną przy pracy, a stopień przeciążenia zależy także od techniki, w której pracuje lekarz stomatolog, warunków ergonomicznych, umiejętności adaptacji pacjenta oraz kooperacji z asystą lub asystami.

Cel pracy: Uzyskanie odpowiedzi na postawione pytania badawcze: czy stomatolodzy posiadają wiedzę na temat zasad ergonomii, czy istnieje związek między stażem pracy a bólem kręgosłupa szyjnego, wiekiem a techniką pracy, czasem pracy w ciągu tygodnia a bólem w odcinku szyjnym kręgosłupa, czy dentyści przywiązują wagę do profilaktyki schorzeń narządu ruchu. Materiał i metody: Materiał badany stanowiło 52 lekarzy stomatologów, w tym 33 kobiety (63,5\%) oraz 19 mężczyzn $(36,5 \%)$. W badaniu wykorzystano anonimową ankietę własną, skalę wizualno-analogową, zmodyfikowany kwestionariusz Laitinena oraz metody statystyki opisowej (test niezależności $\chi^{2}$ Pearsona).

Wyniki: Lekarze mają wiedzę na temat ergonomii pracy. Ponad $60 \%$ respondentów posiada nowoczesne urządzenia, regulowane elektrycznie, a technika pracy zależy od wieku stomatologów. Istnieje zależność między bólem kręgosłupa szyjnego a stażem pracy w zawodzie $(p=0,01122)$. Według dentystów $(48,1 \%)$ ból w odcinku szyjnym kręgosłupa spowodowany jest przez długotrwałe utrzymywanie statycznej postawy ciała, a ćwiczenia kinezyterapeutyczne łagodzą te dolegliwości u 23,1\% badanych. Wnioski: Mimo stosowania zasad ergonomii pracy stomatolodzy są narażeni na występowanie bólów kręgosłupa w odcinku szyjnym. 


\section{Introduction}

The performance of the occupation of a dentist may result in various health hazards, which are related with the effect of many unfavourable physical, chemical, biological, and psychological factors at the workplace [1]. The results of the conducted studies [2] indicate that dentists are an occupational group especially exposed to the occurrence of occupational and para-occupational diseases concerning the musculoskeletal system, associated mainly with a non-ergonomic method of performing work. Dentists most often complain of pain syndromes concerning the lumbosacral and neck regions of the spine, shoulder pain, as well as neuropathies in the hands. In some cases, occupational diseases may be diagnosed, such as humeral epicondylitis ('tennis elbow') and carpal tunnel syndrome [2].

In modern dental ergonomics, the principles of teamwork are promoted in order to reduce the overload of the osteoarticular system in a dentist. The physicians share duties with assistants, relegating from $35 \%$ to $60 \%$ of their activities. This means a decrease of fatigue and the load on the musculoskeletal, visual, and nervous systems in a dentist [3]. The problem of health hazards resulting from the method of performing the occupation of a dentist concerns, among others, the cervical section of the spine. The fact that physicians spend approximately 30-50\% of their working time in a leaning position may increase pain complaints [1]. Such a non-physiological position forces an uneven work load on muscles of the anterior and posterior side of the neck, may lead to shallow cervical lordosis, and consequently, to the natural exploitation of tissues and their overloading. This phenomenon may concern intervertebral discs, facet joints, bone tissue, and the spinal ligaments. A forced, non-ergonomic body position, in combination with immobility and long-lasting contraction of muscles, may lead to acidification, fatigue, and muscle pain, while strong pain may even lead to discontinuation of occupational activity by dentists. Increased cervical pain results in prolongation of the working time of many dentists, which additionally contributes to an excessive exploitation of the body. The performance of work by a dentist is associated with intellectual work, and a greater or smaller amount of physical work, mainly static, and physical and mental load are inseparable elements $[4,5]$.

Dental work covers prophylactic, therapeutic, and rehabilitation activities. In order to cope with these activities the entire dental team should provide this care. The leader of this team is a physician, to whom are subordinated the medium-level dental staff - a hygienist, assistant, and dental technician [6].

Recently, greater attention has been paid to socalled psychosocial factors, i.e. tension, time pressure, responsibility, complexity of work, and its intensity, which may increase pain complaints on the part of the musculoskeletal system. The psychological load of a dentist may be caused by the monotony of work (repeating, to a lesser or greater extent, the same activities), monotypy (repetitive work movements), precision of motor activities (due to the size of the surgical area), necessity to make frequent and difficult decisions (related with the making of diagnosis, course of procedure), and watchfulness (i.e. a state of high concentration of senses, mainly sight and touch) $[5,7]$.

Dentists are an occupational group exposed to the occurrence of cervical pain; therefore, every physician should know how to arrange their own workplace, and how to work with a patient in a way that is consistent with ergonomic principles. Dentists should pay attention to proper prophylaxis, to avoid leading to exclusion from their occupational life, which may cause financial loss, disorganisation of work in a dental room or an outpatient clinic, and may also be harmful for a patient, while the patient's wellbeing should be the main goal of the work of a dentist and the entire dental team $[7,8]$.

\section{Material and methods}

The study group consisted of 52 dentists - 33 females (63.5\%) and 19 males (36.5\%). The completion of a questionnaire was the criterion of enrolment into the study.

The study was conducted using the following methods: an anonymous questionnaire designed by the authors, Visual Analogue Scale (VAS), a modified pain assessment questionnaire according to Laitinen [9], and methods of descriptive statistics.

The questionnaire consisted of 36 items divided into 3 parts concerning: personal data (e.g. gender, age, height, weight, place of work, and duration of employment), work ergonomics (e.g. knowledge of ergonomics, position at work, equipment possessed, help from assistants, methods of work), and pain complaints (among others, intensity of pain, its character, treatment applied, other complaints).

The Visual Analogue Scale (VAS) is a subjective method that allowed determination of the intensity of pain sensation experiences. According to the 10-degree scale, the following intensities of pain were distinguished: 0 - no pain, $1-3-$ mild pain, $4-7$ - moderate pain, $8-10$ - severe pain [10].

A modified questionnaire for the assessment of pain by Laitinen was used for measuring pain according to its intensity and frequency, use of analgesic drugs, and limitation of physical activity [10].

\section{Statistical analysis}

Statistical data were analysed using the software Statistica 6.0. While interpreting the results, the degree of statistical significance of the relationships be- 
tween variables was determined with the use of Pearson's $\chi^{2}$ test for independence [11]. In this test, the zero hypothesis assumes the lack of a relationship between variables (the variables are independent). An alternative hypothesis is that there is a relationship between variables (the variables are dependent). The value of $p<0.05$ was considered statistically significant.

\section{Results}

The results of the study showed that a half of the respondents work 5 days a week, whereas less than $30 \%$ work less than 5 days, mainly those aged 46-60 years and over. Young dentists, mainly those aged $30-45$ years $(21.1 \%)$ admitted that they perform occupational activity more than 5 days a week. A similar situation was observed with respect to the number of working hours a week $-28.8 \%$ of respondents work more than $41 \mathrm{~h}$, less than $12 \%$ have more than 21 patients daily. More than $90 \%$ of the dentists in the study (47) declared that they knew the principles of ergonomics, while only 5 dentists did not possess such knowledge.

A small number of respondents (10) perform work in a standing position, 20 - in a sitting position, and the reminder (22) perform work in both standing and sitting positions. Patients are most often provided treatment in a sitting/semi-sitting position (53.8\%), sitting and prone position (36.5\%), and less than 10\% of dentists place their patients in a prone position (Figure 1).

In a group of 25 physicians working 'single-handed' (independently), 19 experienced pain complaints. There was also a group of 15 dentists who, according to the situation, worked 'two- or four-handed" (with the help of an assistant), and 10 of them complained of pain in the cervical region of the spine (Figure 2).

The smallest number of dentists aged over 60 worked using the 'single-handed' technique. The 'fourhanded' or 'two- and four-handed' methods were applied mainly by dentists aged $30-45$ and over 60 years. However, these data are statistically insignificant (Pearson's $\chi^{2}$ test for independence $p=0.05660$ ).

The investigation of the duration of breaks at work of dentists showed that the majority of them (61.5\%) devoted from 5 to $15 \mathrm{~min}$ to rest. It is an interesting

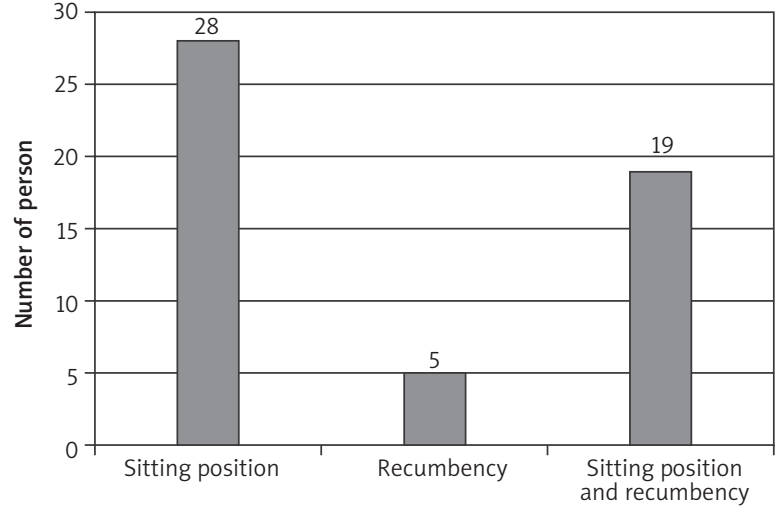

Figure 1. Position assumed by a patient during treatment according to respondents

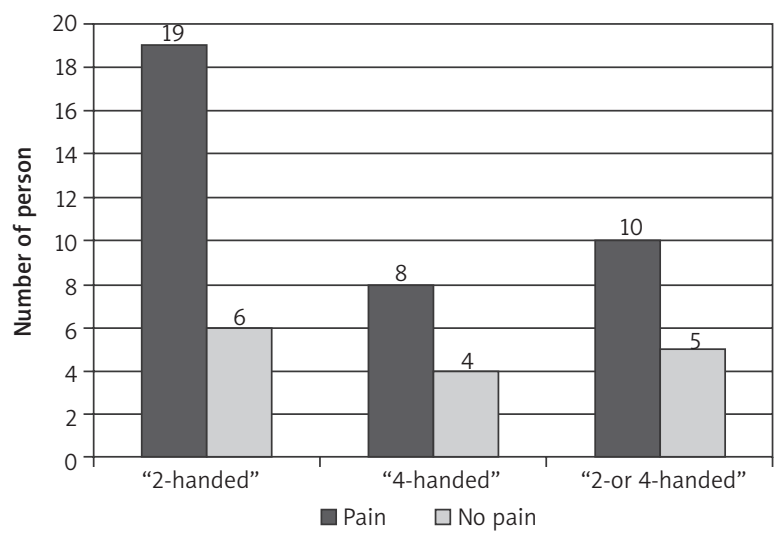

Figure 2. Method of work and occurrence of pain in the cervical region of the spine

fact that 12 respondents did not use any break while performing occupational activity, mainly those aged under 45 years (Table 1 ).

As many as 29 (55.8\%) dentists in the study declared that they often assume a very non-ergonomic position at work, 21 (40.4\%) assumed this position only sometimes, while the remaining 2 physicians $(3.8 \%)$ never assumed this position.

As many as 14 respondents performed simple relaxation exercises during breaks at work, and 11 dentists participated in extra courses that made them

Table 1. Break time during work according to respondents' age

\begin{tabular}{|lccccc|}
\hline Duration of breaks [min] & Respondents, $n(\%)$ & \multicolumn{4}{c|}{ Age [years] } \\
\cline { 3 - 6 } & & Under 30 & $\mathbf{3 0 - 4 5}$ & $\mathbf{4 6 - 6 0}$ & Over 60 \\
I do not take breaks & $12(23.1)$ & 4 & 6 & 1 & 1 \\
$5-15$ & $32(61.5)$ & 8 & 11 & 8 & 5 \\
$15-30$ & $6(11.5)$ & 0 & 1 & 1 & 4 \\
Over 30 & $2(3.8)$ & 0 & 1 & 1 \\
\hline
\end{tabular}




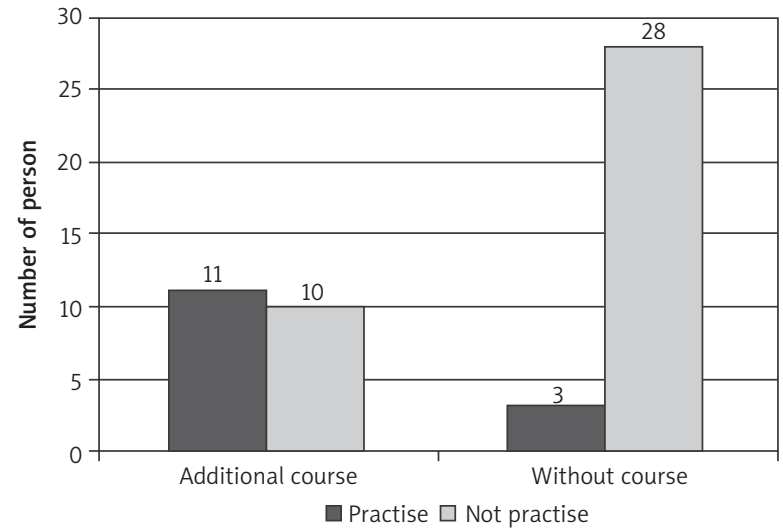

Figure 3. Performance of exercises during break time at work and participation in extra courses in the study group

aware of the risk of loading the musculoskeletal system at work. More than a half of the respondents (28) had not participated in the courses and did not perform exercises during breaks. A statistically significant relationship was found between the performance of exercises during breaks at work and participation in extra courses (Pearson's $\chi^{2}$ test for independence, $p=0.00066$ ) (Figure 3).

No relationship was observed between cervical spine pain and the age of physicians in the study $(p=0.05801)$. Pain complaints were reported by 14 dentists (26.9\%) in the group aged 30-45 years, $9(17.3 \%)$ in the group aged $46-60$ and over, and 5 (9.6\%) among those aged under 30. Summing up, as many as 37 respondents (71.1\%) experienced pain in the cervical region of the spine.

A statistically significant relationship was noted between pain in the cervical region of the spine and duration of performance of the occupation of a dentist ( $p=0.01122$ ). The results of the study showed (Figure 4$)$ that all respondents (100\%) who had a period of employment of more than 31 years (11) experienced pain complaints; 15 (75\%) per 20 dentists with the pe-

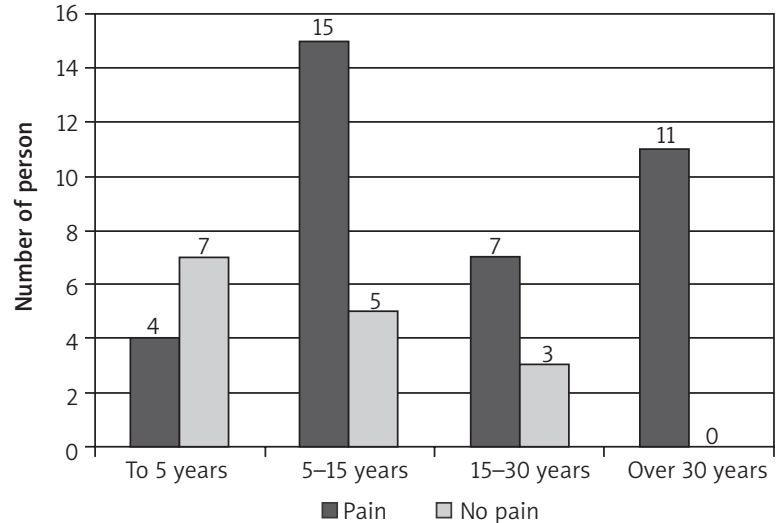

Figure 4. Occurrence of cervical spine pain according to respondents' period of employment

riod of employment 5-15 years experienced pain in the cervical region of the spine, as well as 7 (70\%) who had work experience of 15-30 years. In the group of respondents who had a period of employment up to 5 years only 4 (36.3\%) complained of pain.

The intensity of pain in the cervical region of the spine changed from the moment of undertaking occupational activity until the end of a workday. At the beginning of the day, 36 (69.2\%) respondents did not experience pain, whereas after its completion - only $10(19.2 \%)$ experienced pain. Mild pain was reported by 14 respondents (26.9\%), and at the end of the workday, by 27 (51.9\%) respondents. Severe pain was mentioned by 2 respondents (3.8\%), and at completion of work, by $14(26.9 \%)$ respondents. Severe pain after work occurred in only one respondent.

Considering cervical pain, the number of workdays, and the age of the dentists in the study a relationship was noted, which was close to statistical significance ( $p=0.05121)$. In the group of 15 dentists who worked less than 5 days a week, as many as 14 experienced pain, mainly those aged over 46 years (Table 2).

Table 2. Relationships between pain complaints, age, and number of workdays in the group examined

\begin{tabular}{|lcccc|}
\hline Variable & Age [years] & \multicolumn{3}{c|}{ Number of workdays a week } \\
\cline { 2 - 5 } Pain & Under 30 & Less than 5 days & $\mathbf{5}$ days & More than 5 days \\
& $30-45$ & 1 & 2 & 1 \\
& $46-60$ & 4 & 9 & 4 \\
& Over 60 & 7 & 4 & 1 \\
No pain & Under 30 & 0 & 2 & 0 \\
& $30-45$ & 0 & 4 & 3 \\
& $46-60$ & 1 & 4 & 0 \\
Total & Over 60 & 0 & 1 & 1 \\
\hline
\end{tabular}


Table 3. Relationships between pain in the cervical region of the spine and other sections

\begin{tabular}{|c|c|c|c|c|c|c|c|c|}
\hline \multirow[t]{2}{*}{ Pain in section $C$ of spine } & \multicolumn{7}{|c|}{ Back pain in other section } & \multirow[t]{2}{*}{ Total } \\
\hline & No pain & Th & $\mathrm{L}$ & $\mathrm{S}$ & Th and $\mathrm{L}$ & Th, $\mathrm{L}$ and $\mathrm{S}$ & $\mathrm{L}$ and $\mathrm{S}$ & \\
\hline Yes & 6 & 2 & 4 & 8 & 1 & 2 & 14 & 37 \\
\hline No & 4 & 0 & 3 & 1 & 1 & 0 & 6 & 15 \\
\hline Total & 10 & 2 & 7 & 9 & 2 & 2 & 20 & 52 \\
\hline
\end{tabular}

As many as $40.4 \%$ of dentists described presently experienced pain in the cervical region of the spine as blunt and disseminated, $34.6 \%$ - as radiating, and only $3.8 \%$ - as acute.

According to $48.1 \%$ of respondents, pain complaints are caused by long-lasting static body position; $23.1 \%$ of them considered that kinesitherapeutic exercises alleviate pain complaints concerning the cervical region of the spine; and $28.8 \%$ of dentists took analgesic drugs or combined them with exercises according to the McKenzi method (19.2\%). In $42.3 \%$ of respondents the treatment brought about the expected outcome.

In 14 respondents, apart from pain in the neck section of the spine, they also described pain in the lumbosacral region, and 2 respondents experienced pain in the cervical thoracic, lumbar, and sacral sections (Table 3).

The dentists also complain of dizziness during work $(3.8 \%)$, shoulder pain $(15.4 \%)$, and wrist pain (17.3\%). These symptoms occurred separately or together (21.2\%). Due to the high risk of overload and degenerative changes, more than a half of the respondents $(67.3 \%)$ attached importance to prophylactic examinations.

Among the respondents, currently experienced pain in the cervical region of mediocre intensity was reported by 20 dentists (38.5\%), $16(30.8 \%)$ evaluated the intensity of pain as low, only $1(1.9 \%)$ as high, while 15 respondents $(28.8 \%)$ did not mention any pain (acc. to VAS).

The results of a modified pain assessment questionnaire according to Laitinen indicated that 30 respondents $(57.7 \%)$ experienced mild pain, occurring periodically, which did not cause limitation of locomotor activity. Nearly $20 \%$ of respondents did not experience pain (10), and $11(21.2 \%)$ perceived pain as severe. Only 15 dentists (28.8\%) did not apply analgesics, and 30 took these drugs occasionally; $34.6 \%$ (18) declared partial limitation of locomotor activity due to pain.

\section{Discussion}

There is an increasing amount of evidence that the unique work conditions in dentistry may exert a considerable effect on the health of physicians. The results of a survey conducted in a group of 1,670
Lithuanian dentists showed that the majority of them $(80.8 \%)$ considered their occupation as physically demanding, $16.9 \%$ of respondents partially agree with this, and approximately $2.3 \%$ entirely disagreed with such a statement. More than a half of respondents (50.4\%) described their state of health as satisfactory, and $46.6 \%$ as good or very good. The minority, only $3.4 \%$ of respondents, evaluated their state of health as very good, while $3 \%$ as poor or very bad [12]

Dentists usually perform their occupation in a standing and sitting position. Strojek et al. [13] reported that in a group of 20 respondents, the largest number, i.e. a half of them, worked in the above-mentioned positions. The preferred patient position was the prone position $[14,15]$. The majority of a group of 140 dentists in South Arabia, as many as 95 (67.9\%), when asked to describe their standing position in terms of the hands on a clock, described assuming a position between the hours of 10:00 and 12:00 on the clock face, the centre of which is placed at the height of the patient's mouth. Dentists who worked at the 09:00 position reported more complaints (76.5\%) than those working at the 10:00 position (48.3\%). Only 17 respondents worked at the $12: 00$ position and mentioned complaints concerning the neck and back [14].

The majority of dentists in the examined group (42) possessed modern, electrically adjustable equipment, which enabled assumption of the correct body posture. Tuszyński and Lella consider that implementation of modern equipment of the unit type, with an ergonomic seat for the dentist, prone position for the patient, and an adjustable bolster, facilitates the performance of procedures and reduces overload of the neck muscles and cervical spine of the physician [15].

Bladowski et al. consider that a physician who works in a team shares $35-60 \%$ of the activities performed with assistants, compared to performing work by the solo method [3]. According to reports, the most advantageous method of work is the 'four-handed' or 'six-handed' technique, because with such an organisation of work the load is distributed among 2-3 persons. Unfortunately, the results of the survey demonstrated that less than $1 \%$ of Polish dentists work 'four-handed'. Not a single physician was found who would work by the 'six-handed' technique [15], a technique that is new in Poland and unwillingly practiced due to economic 
reasons [16]. The studies carried out in South Arabia indicated that as many as $89 \%$ of the dentists examined work by the 'four-handed' method [14].

The long working time of many physicians, which is even more than $10 \mathrm{~h}$ daily, results in excessive exhaustion of the body [7]. The results of our own studies show that $23.1 \%$ of respondents do not take any breaks while performing occupational activity.

The specificity of profession requires from dentists the assumption of a forced body position at work. According to Lewczuk et al., dentists remain in a leaning position for approximately $30-50 \%$ of their working time. In addition, they perform from $100-300$ bends, and from 800-1000 repeated movements of the upper extremities, from full bend to upright [1]. The results of our own studies show that from among 52 respondents as many as 29 (55.8\%) very frequently assume non-ergonomic positions.

Musculoskeletal pain has been considered as a serious health problem among dentists; hence, there are many studies describing these complaints [17]. In a group of 20 respondents, as many as $16(80 \%)$ had shallow cervical lordosis. In addition, an abnormal positioning was noted of the head and neck (70\%), shoulders (85\%), and waist triangles (90\%). An increased tension of the paraspinal muscles in the neck section was observed in 8 respondents (40\%). Pathological changes begin early, i.e. in the neck section after 11 years, in the lumbar section after 13 years, and in both sections simultaneously after 15 years [13]. Degenerative changes in the neck section of the spine cause limitation of all movements on both sides of the spine. Greater limitations occur on the painful side, and concern mainly the rotation of the spine towards the painful side (46.9\%) [4].

The results of the presented study indicate that the duration of performing the occupation exerts an effect on the occurrence of pain in the cervical region of the spine in dentists. In Queensland, Australia a survey was conducted which confirmed that 248 dentists $(87.2 \%)$ had experienced at least one symptom of musculoskeletal disorders within the last 12 months. Complaints concerning the neck were most often reported $(57.5 \%)$. It is an interesting fact that pain in this region more frequently occurred in young respondents, who had less professional experience. More than one third of all dentists (37.5\%) sought advice or had undertaken treatment within the last 12 months [18]. Lithuanian physicians aged 34 and under evaluated their state of health as satisfactory (24.6\%), while some of them $(1.3 \%)$ evaluated it as poor or very bad. Physical disorders may occur at the beginning of a dental career, especially among students. These facts emphasise the importance of paying attention to health as soon as during university studies, and becoming familiar with the principles of ergonomics, early diagnostics, and treatment of profession-related diseases [12]. The presented study showed that 14 dentists $(26.9 \%)$ perceived pain complaints in the cervical, lumbar, or sacral sections of the spine. In two respondents pain occurred in the cervical, thoracic, lumbar, and sacral sections. Presently experienced cervical spine pain was described as: blunt and diffused $(40.4 \%)$, radiating $(34.6 \%)$, and acute $(3.8 \%)$.

Strojek et al. [13] reported that the use of complex and integrated rehabilitation (massage, kinesitherapy, paraffin, Sollux lamp, Terapuls device, ultrasound, diadynamic current, galvanic current, cryotherapy) resulted in an improvement in 14 respondents (70\%), while in $6(30 \%)$ no improvement was noted. The results of the presented study indicate that in order to decrease pain in the cervical region of the spine 15 (28.8\%) dentists in the study took analgesics or combined them with exercises according to the McKenzie method (19.2\%). In 22 dentists (42.3\%) the treatment procedures brought about the expected outcomes.

Also psychosocial factors, such as tension, rush, responsibility, and complexity of work and its intensity, may affect the occurrence of pain complaints on the part of the musculoskeletal system [7]. There is a relationship between the occurrence of chronic cervical spine pain syndrome, and depression, and experiencing emotions such as fear, anxiety, concern, or humiliation [19].

\section{Conclusions}

Dentists possess knowledge concerning the principles of ergonomics, which they should use while performing their occupation. A statistically significant difference was observed between the period of performance of the occupation of a dentist and occurrence of pain in the cervical region of the spine. No statistically significant relationship was found between age and the technique of performing work by a dentist in the group in the survey. No statistically significant difference was noted between working time during the week and occurrence of pain in the cervical region of the spine in the examined group. Dentists pay great attention to the prophylaxis of diseases of the locomotor organ.

\section{Conflict of interest}

The authors declare no conflict of interest.

\section{References}

1. Lewczuk E, Affelska-Jercha A, Tomczyk J. Zawodowe zagrożenia zdrowotne $\mathrm{w}$ gabinetach stomatologicznych. Medycyna Pracy 2002; 53: 161-5.

2. Krawczyk-Adamus P, Pałczyński C. Wpływ pracy zawodowej na układ ruchu lekarzy stomatologów. Twój Przegląd Stomatologiczny 2005; 11: 48-50.

3. Bladowski M, Bogdan M, Kołakowska-Woźniczka B, et al. Wstęp do ergonomii pracy w stomatologii ogólnej. Magazyn Stomatologiczny 2001; 1: 10-4. 
4. Barczyk K, Skolimowski T, Jasiński R, et al. Wpływ zmian zwyrodnieniowych kręgosłupa szyjnego na zaburzenia czynnościowe narządu ruchu kobiet $\mathrm{w}$ średnim wieku. Fizjoterapia 2006; 14: 53-8.

5. Bladowski M. Stomatologia zachowawcza w znieczuleniu ogólnym. Tryb ambulatoryjny. Podstawy ergonomii pracy zespołu stomatologicznego i zasady zespołowych technik pracy podczas zabiegów wykonywanych w znieczuleniu ogólnym. Nowa Stomatologia 2002; 2: 73-87.

6. Skomro P, Opalko K, Szumiłowicz P. Nowe zadania dla higienistki stomatologicznej $\mathrm{w}$ gabinecie. Asystentka i Higienistka Stomatologiczna 2006; 1: 46-7.

7. Piątkowska A, Szymańska J. Choroby zawodowe i parazawodowe układu ruchu u stomatologów. Zdrowie Publiczne 2009; 119: 228-30.

8. Szubert Z, Sobala W. Czasowa niezdolność do pracy osób z przewlekłymi chorobami narządu ruchu wywołanymi sposobem wykonywania pracy. Medycyna Pracy 2001; 52: 87-94.

9. Laitinen J. Acupuncture and transcutaneus electric stimulation in the treatment of chronic sacrolumbalgia and ischialgia. Am J Chin Med 1976; 4: 169-75.

10. Depa A, Wolan A, Przysada G. Wpływ rehabilitacji na zmianę ruchomości kręgosłupa z zespołem bólowym w odcinku lędźwiowym. Przegląd Medyczny Uniwersytetu Rzeszowskiego 2008; 2: 116-24.

11. Krysicki W, Bartos J, Dyczka W, et al. Rachunek prawdopodobieństwa i statystyka matematyczna w zadaniach. Cz. 2. Statystyka matematyczna. Wyd. 8. PWN, Warsaw 2006.

12. Puriene A, Aleksejuniene J, Petrauskiene J, et al. Self-reported occupational health issues among Lithuanian dentists. Industrial Health 2008; 46: 369-74.

13. Strojek K, Bułatowicz I, Chilimoniuk K, et al. Nieergonomiczna praca stomatologów jedną z przyczyn rozwoju zmian zwyrodnieniowo-zniekształcających kręgosłupa. Collegium Medicum UMK w Bydgoszczy, Bydgoszcz 2009; 378-83.

14. Abduljabbar T. Musculoskeletal disorders among dentists in Saudi Arabia. Pakistan Oral and Dental 2008; 28: 135-44.

15. Tuszyński K, Lella A. Choroby zawodowe lekarzy stomatologów. Via Medica, Gdańsk 2009.

16. Tananis S, Goczewski M, Bladowski M, Wysokińska-Miszczuk J. Analiza obciążeń układu nerwowego i mięśniowo-szkieletowego u operatorów w stomatologii pracujących w mikroskopie operacyjnym. As Stomatologii 2008; 6: 26-30.

17. Leggat P, Kedjerune U, Smith D. Occupational health problems in modern dentistry: a review. Industrial Health 2007; 45: 611-21.

18. Leggat P, Smith D. Musculoskeletal disorders self-reported by dentists in Queensland, Australia. Aust Dent J 2006; 51: 324-7.

19. Szczygieł E, Krzanik B, Golec J, Szot P. Rola czynników psychologicznych w przewlekłych zespołach bólowych kręgosłupa szyjnego. Fizjoter Pol 2009; 4: 312-20.

\section{Address for correspondence:}

\section{Jędrzej Płocki MD}

Szpital Specjalistyczny im. Świętej Rodziny

Rudna Mała 600, 36-060 Głogów Młp.

Phone: +48 178666700

E-mail: jplocki@gazeta.pl 